\title{
GIS modelling based on slope and morphology for landslide potential area in Wonosobo, Central Java
}

\author{
Muhammad Chaidir Harist ${ }^{1, *}$, Humam A. Afif ${ }^{1}$, Dian Nurahandayani Putri $^{l}$, Iqbal Putut Ash Shidiq ${ }^{l}$ \\ ${ }^{1}$ Geography, University of Indonesia, UI Campus, Depok, 16424, Indonesia
}

\begin{abstract}
National Agency for Disaster Management (BNPB) noted since early 2017 to December $4^{\text {th }}, 2017$ recorded as many as 577 incidents of landslides throughout Indonesia. Based on Indonesia Disaster Information Data (DIBI) within 2017 until now in Wonosobo District there are 9 landslide events and one of them is in Wadaslintang Sub-District where causing fatalities and material loss. Many factors can cause landslides such as rainfall, slope, geological soil type and vegetation density, which is slopes are a major factor in some landslide disaster cases. Therefore, to anticipate the loss of both casualties and material losses more in Wonosobo Regency, it is necessary to conduct a study in order to obtain landslide potential areas. The model applied to determine landslide potential areas is the SMORPH model approach by implementing slope morphology and angle/gradient of the slopes using Geographic Information System (GIS). From the results of data processing found that the area of landslide potential with the highest grade in Wonosobo district of $17 \%$ area, and for sub-district and the sub-district with the highest potential landslide is Wadaslintang with the percentage of $13.85 \%$ area. Landslides can affect a variety of land uses, and the most widely affected is a plantation with $87,07 \mathrm{Km}^{2}$
\end{abstract}

\section{Introduction}

Definition of disaster based on Law Number 24 of 2007 is an event or series of events that threaten and disrupt the life and livelihood of the community caused by both natural and/or non-natural factors and human factors resulting in the occurrence of human lives, damage environment, property loss, and psychological impact. One of disaster with the most frequent occurrence is a landslide. National Agency for Disaster Management (BNPB) noted since the beginning of 2017 to December 4th, 2017 recorded 577 incidents of landslides throughout Indonesia. A landslide is the movement of rock, earth, or debris down a sloped section of land (National Geographic, 2014).

Major factors that caused a landslide are nature condition and human activity. Nature condition such as Geology refers to material characteristics itself. morphology refers to the landscape structure of the earth. The trigger factors that make landslide happen are rain, land cover, slope, etc. [1]. Today, Indonesia is starting the rain season, which means the risk of the landslide is increasing. Landslides have negative effects, damage to infrastructures such as road, buildings, communication system, and the deaths of people.

Some of the places in Indonesia are in high risk status for the landslide. One of them is Wonosobo Regency in Central Java. In November 2017, 15 houses of citizens Wadaslintang, Wonosobo, damaged by landslides after heavy rain. According to BPBD
Wonosobo, a total of 13 damaged houses occurred in Sipes Village seven houses, Kesenep one house, and Kalisalak five houses. In addition to damaged houses, there are 16 points of the road and one bridge also damaged in Wadaslintang. Many factors that cause landslides, in addition to heavy rainfall, slopes and morphology in a region also need to be considered.

Not only the logistical support required by the landslide victims, but preventive measure to reduce material and fatalities losses are also required so that similar incidents do not continue to recur.

The purpose of this research is to identify which region in Wonosobo Regency that has potential landslides and to reduce the impact of material losses and fatalities. Geographic Information System (GIS) can be used to analyze the spatial distribution of potential location to landslides. In the identification required various kinds of data such as daily rainfall from the rainfall station in the area concerned, slope constituent rocks, soil type, and the other. Limited data is not an obstacle to the identification of landslide potential areas, where there is a method that can be used with limited data. Therefore, it can be produced a mapping for landslide potential areas in the Wonosobo Regency.

\subsection{Description of research area}

Wonosobo regency is one of the regencies in Central Java province, with the capital of Wonosobo and located $120 \mathrm{Km}$ northwest of Semarang city. Geographically

* Corresponding author: chaidirharist@gmail.com 
Wonosobo Regency is located at 70.11'.20 "to 70.36'.24" South Latitude (LS), and 1090.44'.08 "to 1100.04'.32" East Longitude (BT), with an area of 98,468 hectares $\left(984,68 \mathrm{Km}^{2}\right)$ or $3.03 \%$ of the province of Central Java. The area is administratively divided into 15 districts. The boundaries of Wonosobo regency can be detailed as follows:

1. Regency of Banjarnegara, Regency of Kendal and Regency of Batang in the north;

2. Regency of Temanggung and Regency of Magelang in the east;

3. Purworejo and Kebumen districts in the south;

4. Regency of Banjarnegara and Kebumen Regency in the west.

\section{Material and method}

There is some material and method for determining landslide potential area. In this research, the materials used the only Slope from Digital Elevation Model (DEM), and the material is processed using the Slope and Morphology method by utilizing ArcGIS 10.1 technology.

\subsection{Material}

To determine landslide potential areas required some materials. In this research to know the landslide potential area and what kind of land use got the impact from the landslide, used materials like Slope from DEM, and land use.

\subsubsection{Slope}

The Slope is the appearance of the natural surface because of the high difference if the height difference between the two places is compared with the horizontal straight distance so that the slope will be obtained [2]. The shape of the slope depends on the process of erosion, soil movement, and weathering. The slope is a topographic parameter that is divided into two parts: the slope and the high relative height, where the two parts have a major influence on the assessment of critical materials.

The Slope is a measure of elevation change. This is an important parameter in some of the well-known predictive models used for environmental management, including Universal Soil Loss Equation and nonagricultural source pollution models. One way to express the tilt is as a percentage. To calculate the percent slope, then multiply the quotient by 100 . The elevation difference between points is called an increase. The distance between dots is called run. Thus, the percent slope equals (rides / runs) x 100.

Landslide is affected by slope, landslides with flat slopes have less potential, and if slopes are steeper have a higher landslide potential [3]. In this research, the slope must be classification according to Van Zuidam. Van Zuidam has divided the slope into some classes as below.
Table 1. Slope gradient in percent (Bermana I., 2006)

\begin{tabular}{|c|c|c|}
\hline Num & Class & Description \\
\hline 1 & $0-2 \%$ & Flat \\
\hline 2 & $2-15 \%$ & Moderate \\
\hline 3 & $15-25 \%$ & Moderate Steep \\
\hline 4 & $25-40 \%$ & Steep \\
\hline 5 & $>40 \%$ & Very Steep \\
\hline
\end{tabular}

Shapes of the slope can be obtained through the classification below.

Table 2. Shapes of slope (Putra, 2014)

\begin{tabular}{|c|c|c|}
\hline Num & Curvature & Curvature Value \\
\hline 1 & Convex & $>0,01$ \\
\hline 2 & Planar & $-0,1$ to 0,01 \\
\hline 3 & Concave & $<-0,1$ \\
\hline
\end{tabular}

\subsubsection{Digital elevation model (DEM) 2015}

The DEM data used in this study is the SRTM (Shuttle Radar Topographic Mission) 1 Arc-Second Global with $30 \mathrm{~m}$ resolution obtained from United States Geological Survey (USGS) with URL address: https://earthexplorer.usgs.gov/. SRTM 1 Arc-Second Global elevation data offer worldwide coverage of void filled data at a resolution of 1 arc-second (30 meters) and provide open distribution of this global high-resolution data set. Some tiles may still contain voids. DEM represents spatial variation in altitude and is used in producing slope gradient and slope shape [4]. The Slope is an important parameter for determining landslideprone areas

\subsubsection{Land use 2013}

In general, land use in Indonesia is a tangible result of the long process of permanent interaction, balance and dynamic state of population activities on land and limitations in living environment (As-syakur et al., 2010). The general land use form in Wonosobo Regency can be divided into 13 categories, namely technical irrigation rice field, semi-technical irrigation paddy field, simple irrigation field, rainfed rice field, yard, state forests, community forests, plantations, and other uses. The largest area in Wonosobo Regency is used for mooring/plantation. Moor in Wonosobo District is used for the cultivation of potato, vegetables, and tobacco which has become a tradition of the community. Meanwhile, the second largest land area in Wonosobo Regency is for state forest. 


\subsection{Method}

The method used for the identification of landslide-prone areas using the SMORPH method developed by Shaw and Johnson [5]. The SMORPH method classifies slope classes and slope morphology classes consisting of concave, convex and planar forms. The SMORPH matrix is formed by incorporation between slope angle (in\% units) and slope shape (concave, convex and flat). The landslide classification using the SMORPH method based on the matrix between the slope angle and the slope shape.

Table 3. The Relation between shape and gradient slope (Putra, 2014)

\begin{tabular}{|c|c|c|c|c|c|}
\hline \multirow{2}{*}{$\begin{array}{c}\text { Slope } \\
\text { Shape }\end{array}$} & \multicolumn{5}{|c|}{ Slope Gradient } \\
\cline { 2 - 6 } & A & B & C & D & E \\
\hline Convex & & & & & \\
\hline Planar & & & & & \\
\hline Concave & & & & & \\
\hline
\end{tabular}

From that matrix, green color means low class, yellow color means moderate class, and red color means high class for landslide potential area. In this research, the data collected are primary data. The primary data used in this research is the result of DEM SRTM processing through ArcGIS software.

The processing of DEM data through several processes. The first is the process of making Slope using the Slope tool in the ArcGIS software and then classifying the result of the Slope. The second is the process of making the shape of the slope using the Curvature tool and then classifying the results of the Curvature. Last is the process of combining both the classification results of Slope and Curvature by using the Overlay Intersect tool, where the results of the overlay can be classified again based on the SMORPH Matrix.

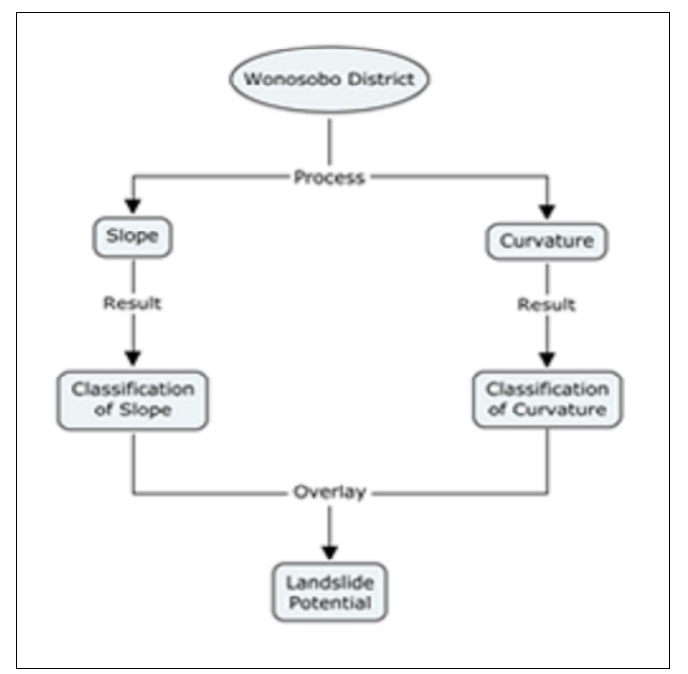

Fig. 1. Mind map of potential landslide area in Wonosobo

The figure above show the stages of data processing. First process is DEM data (2015), by using tool slope to get a percent of slope, after that reclassify the data using Van Zuidam classification for percent of slope, and convert data to the polygon. To get the morphology of slope, it uses curvature tool then reclassifies the data using classification from literature.

After getting both data (slope gradient and slope morphology), then both are overlaid. Next, add a new field for the potential landslide. Add new field again for the sum of each class potential area. For land use map is using map from Badan Informasi Geospasial (BIG); used in this research is the map in 2013. Finally, researchers overlay the landslide potential area map with the land use map, and then the results of the impacted land use area are obtained.

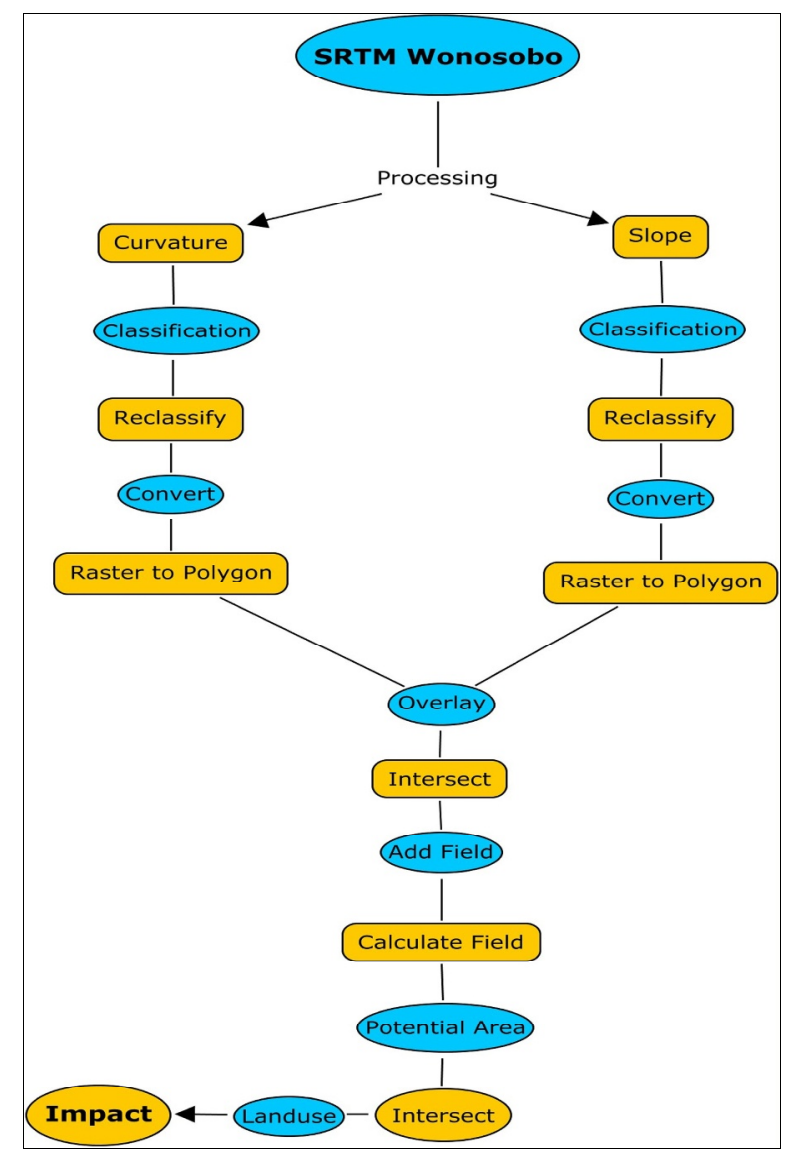

Fig. 2. Mind map of potential landslide area in Wonosobo

\section{Results and discussion}

Wonosobo District is located in Central Java, $120 \mathrm{~km}$ from Capital City of Central Java (Semarang). Wonosobo has altitude $250 \mathrm{~m}-2250 \mathrm{~m}$ with the area around 98.468 ha $(984,68 \mathrm{~km} 2)$ or $3,03 \%$ from the area of Central Java. This district has 15 sub-districts. 700.000 people, with density 710/km2 (BPS, 2010)

Wonosobo has a tropical climate with two seasons, these are dry and rainy season. The average of rainy days is 196 days with precipitation level $3400 \mathrm{~mm} /$ years. The highest is in Garung sub-district $(4802 \mathrm{~mm})$ and the lowest is in Watumalang $(1554 \mathrm{~mm})$. Wonosobo has fertile land that can be planted with many corps. Types of the soil are andosol, regosol, and podzolic. 
The results of the SMORPH method that has been used for the result identification of landslide potential area have three classes; high, moderate, and low. The results of the analysis on the SMORPH method indicate that a low potential region exists on the convex shape of the slope. In the data that has been processed, the higher slope of Wonosobo in accordance with the shape of the slope, the high probability of potential landslides. After completion of data processing based on the predetermined variable, it produced the map of potential landslide area using SMORPH method in Wonosobo as follows.

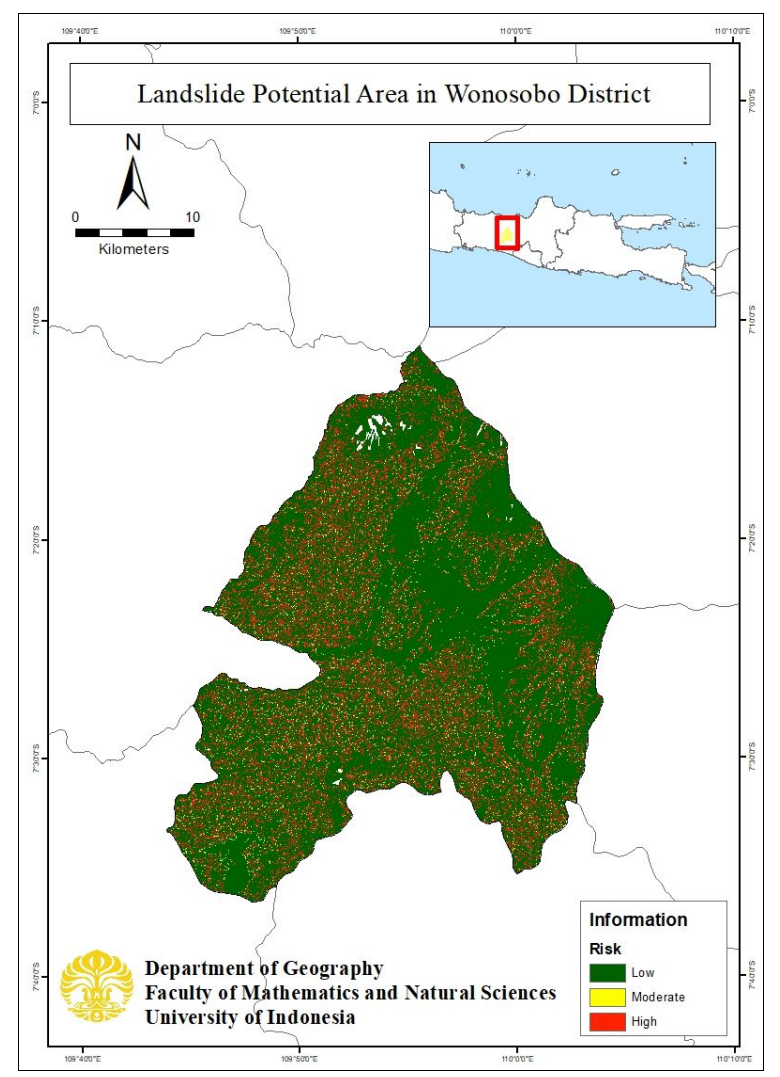

Fig. 3. Map of landslide potential area in Wonosobo

Based on the landslide potential map, it can be seen that Wonosobo Regency is dominated by low and high landslide hazard level. Potential low landslide areas almost spread evenly throughout the Wonosobo Regency. But for high potentials tend to spread randomly, and tend to accumulate in the Southwest and Northwest Wonosobo Regency. Potential landslideprone areas with moderate levels also spread randomly throughout the Wonosobo Regency. From the data processing obtained also the extent of each class of potential landslide hazard areas.

Table 4. Area of landslide potential area

\begin{tabular}{|l|c|}
\hline \multicolumn{1}{|c|}{ Landslide Potential Area } & Area $\mathbf{( K m}^{\mathbf{2}} \mathbf{)}$ \\
\hline Low & 798,256 \\
\hline Moderate & 26,18167 \\
\hline High & 167,3357 \\
\hline Total & $\mathbf{9 9 1 , 7 7 7 3}$ \\
\hline
\end{tabular}

From the table above, landslide-potential areas with low class dominate in Wonosobo Regency with $80 \%$ of the area, then followed by high landslide level that spread randomly with the total area covered $17 \%$. Landslide-potential areas with moderate class are not dominant in Wonosobo because only as large as $3 \%$.

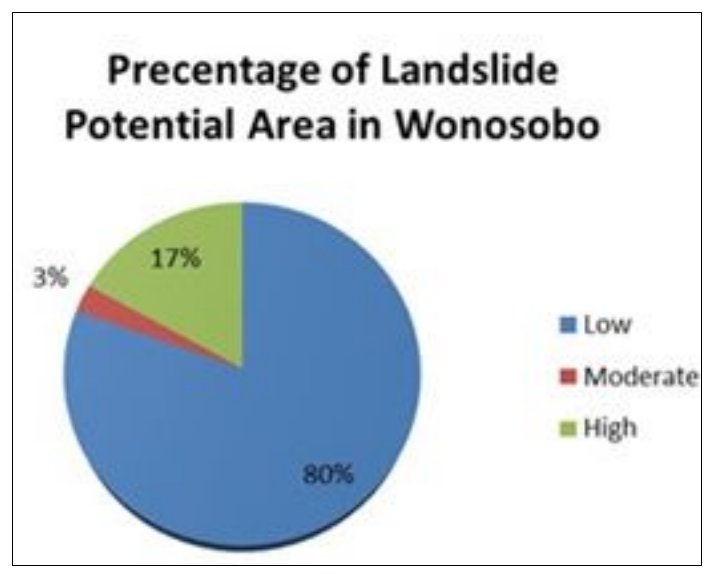

Fig. 4. Percentage of landslide potential area in Wonosobo

Wonosobo is divided into 13 districts. Based on the produced map, the region that has the biggest potential landslide are Wadaslintang District and Selomerto District.

Table 5. Landslide potential of Wadaslintang

\begin{tabular}{|c|c|c|c|}
\hline Potential & $\begin{array}{c}\text { Area } \\
\mathbf{( K m}^{\mathbf{2}} \mathbf{m}\end{array}$ & $\begin{array}{c}\text { Percentage } \\
\text { from District } \\
\mathbf{( \% )}\end{array}$ & $\begin{array}{c}\text { Percentage } \\
\text { from Regency } \\
\mathbf{( \% )}\end{array}$ \\
\hline Low & 108.558 & 79.011 & 10.94873926 \\
\hline Moderate & 4.5164 & 3.287 & 0.455506605 \\
\hline High & 24.3214 & 17.702 & 2.452962168 \\
\hline TOTAL & $\mathbf{1 3 7 . 3 9 6}$ & $\mathbf{1 0 0 . 0 0 0}$ & $\mathbf{1 3 . 8 5 7}$ \\
\hline
\end{tabular}

Table 6. Landslide potential of Selomerto

\begin{tabular}{|c|c|c|c|}
\hline Potential & $\begin{array}{c}\text { Area } \\
\mathbf{( k m}^{2} \mathbf{)}\end{array}$ & $\begin{array}{c}\text { Percentage } \\
\text { from } \\
\text { District } \\
\mathbf{( \% )}\end{array}$ & $\begin{array}{c}\text { Percentage } \\
\text { from Regency } \\
\mathbf{( \% )}\end{array}$ \\
\hline Low & 27.5622 & 84.566 & 2.779816699 \\
\hline Moderate & 0.789888 & 2.424 & 0.079665043 \\
\hline High & 4.24047 & 13.011 & 0.427677374 \\
\hline TOTAL & $\mathbf{3 2 . 5 9 3}$ & $\mathbf{1 0 0 . 0 0 0}$ & $\mathbf{3 . 2 8 7}$ \\
\hline
\end{tabular}

Based on Indonesia Disaster Information Data (DIBI) within 2017 until now in Wonosobo regency there are 9 landslide events with 2 people suffer and evacuate, 10 high damaged houses, 4 moderate damaged house, and 8 less damaged house. According to the table, 
Wadaslintang is the highest landslide potential area which could endanger the population there.

Because there is no survey to Wonosobo, it can be seen through Google Earth with the year adjusted for SMORPH results to prove whether the results of the SMORPHis correct or not.

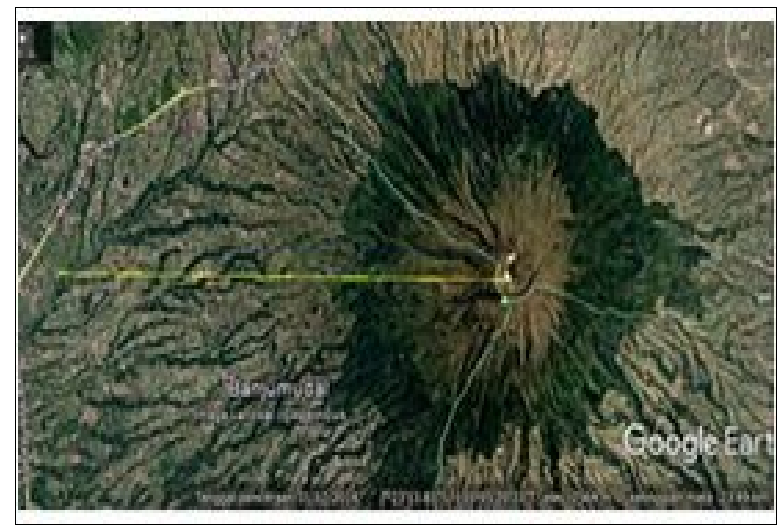

Fig. 5. Transect Line by Google Earth

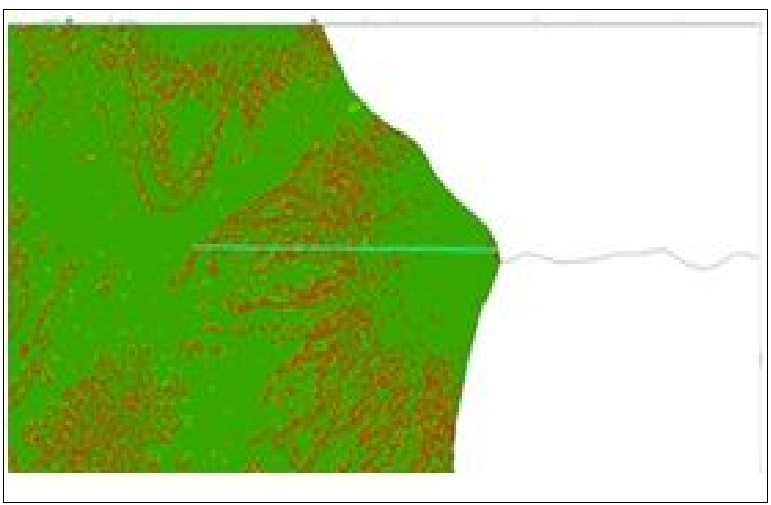

Fig. 6. Transect line in arc map

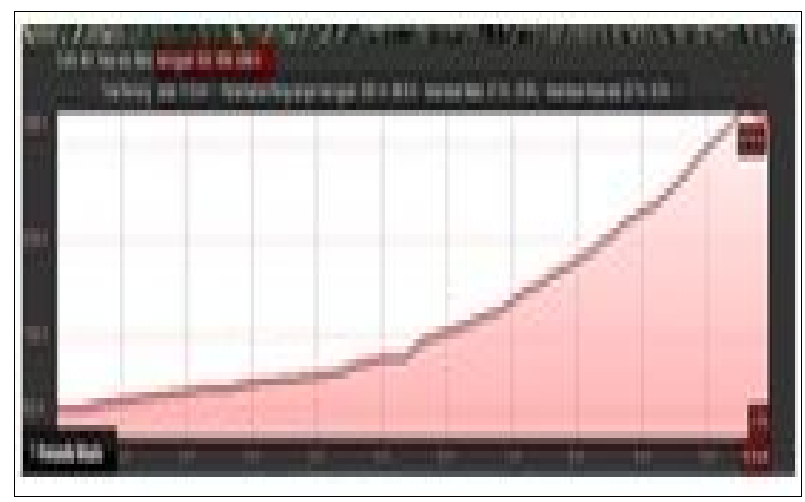

Fig. 7. Elevation level

After identify the potential landslide area, the nest step is to identify the relationship between land use and landslide potential as a form of disaster mitigation where the result of landslide potential area is processed by overlay with land use map and calculated the extent.

From the landslide potential area, it can estimate the affected area if landslides occured. The areas that will be most affected are areas with high level of landslide potential area.
Table 7. Possibly the area affected by landslide in Wonosobo

\begin{tabular}{|c|c|c|}
\hline Potential & Landuse & Impact Area $\left(\mathbf{K m}^{\mathbf{2}}\right)$ \\
\hline High & Freshwater & 0,659485 \\
\hline High & Bush & 8,807791 \\
\hline High & Building & 0,001241 \\
\hline High & Forest & 1,497308 \\
\hline High & Plantation & 87,07589 \\
\hline High & Settlement & 9,057277 \\
\hline High & Grass & 0,312293 \\
\hline High & Irrigated Rice Field & 1,977677 \\
\hline High & Rain-fed Rice Field & 24,87987 \\
\hline High & Field & 33,07176 \\
\hline
\end{tabular}

The largest of land use affected if landslide in Wonosobo occured is plantations with total area 87,07 $\mathrm{Km}^{2}$. The second area that can be affected is fields with total area $33,07 \mathrm{Km}^{2}$, and the third area is Rain-fed Rice Fields with total area $24,87 \mathrm{Km}^{2}$. Wonosobo regency is dominated by land use in the form of plantations and moorings/fields. Settlements area will not be affected too much when the landslide occurred in Wonosobo, but to prevent the occurrence of material losses and casualties it is necessary to do mitigation.

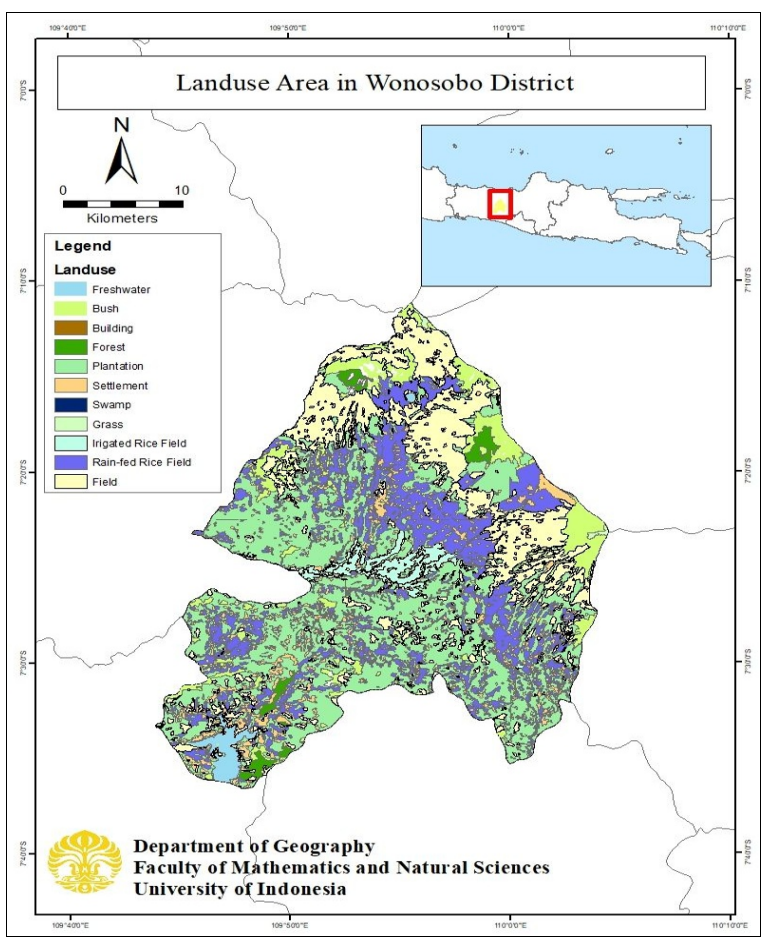

Fig. 8. Land use in Wonosobo 


\section{Conclusion}

The SMORPH method applied in Wonosobo Regency produces a level of landslide potential areas. The low level located in almost all of Wonosobo Regency with $80 \%$ total area; the moderate level that tends to accumulate in the Southwest with 3\% total area, and the high potential level build up in the south with $17 \%$ total area.

The area with the greatest landslide potential is located in Wadaslintang District with $13.857 \%$ and the lowest is in Selomerto District with $3.287 \%$ of the total Wonosobo area.

Landslides can affect a variety of land uses, such as plantations, moor, fields, settlements, and many more. The most affected land use when landslides occurred in Regency of Wonosobo is a plantation with total area $87,07 \mathrm{Km}^{2}$, moor/field with total area $33,07 \mathrm{Km}^{2}$, and Rain-fed Rice Field with total area $24,87 \mathrm{Km}^{2}$. The results of this research is expected to be used for mitigation measures in preventing the occurrence of material losses and casualties due to landslides.

\section{References}

1. M. Souisa, L. Hendrajaya, G. Handayani. Journal of Physics: Conference Series, Vol. 739. (2016)

2. L. Triwahyuni, Sobirin, R. Saraswati. Industrial Workshop and National Seminar. 69-76. (2017)

3. I. Sinarta, A. Rifa'i, T. F. Fathani, W. Wilopo. Geosciences J. Vol. 7, 110. (2017)

4. Putra, E. H. Wasian J. Vol.1 No.1, 1-7. (2014).

5. D. C Erman, F. Ligon. Scanned for KRIS. (1995) 